\title{
METHODOLOGICAL APPROACHES TO PUPILS’ ECOLOGICAL CULTURE EDUCATION
}

\author{
SVITlana SOVHIRA, NATAlita DUSHECHKINA* \\ Ukraine, Pavlo Tychyna Uman State Pedagogical University \\ *Corresponding author e-mail: lab.eco@udpu.edu.ua
}

Received: $19^{\text {th }}$ September 2017 , Accepted: $29^{\text {th }}$ April 2018

\begin{abstract}
The methodological approaches to pupils' ecological culture education such as axiological and cultural had been revealed in the article.

Theoretical methods: analysis and generalization of literature on the research problem; empiric: observation, conversation, pedagogical experiment were used in the process of research.

Based on the use of the above methods it was stated that axiology can consider the problem of the relationship between man and nature from the perspective of values, learn the range of ecological values occuring in human activities, carry out an educational influence on the formation of ecological culture. It was investigated that in terms of axiological approach, values are correlated with various aspects of human nature (the spiritual, moral, psychological, and biological).

The purpose of the article is to reveal the main methodological approaches (axiological and culturological) and apply them for the development of technology for raising the ecological culture of pupils.

Materials of the research can be used for raising the ecological culture of of pupils in secondary schools and out-of-school educational institutions, will become the basis of educational and methodical publications on the education of pupils' environmental culture, can be used by of pupils' self-government and class leaders in educational work with pupils.

It was revealed that the cultural approach to pupils' ecological culture education allows determining the ratio of the ecological culture to the general and spiritual culture, considering the relationship between three social and natural subjects: people, culture, and nature. It was proved that the methodological approaches (axiological and cultural) substantiate the updating of environmental education component, ecological culture development goals, ideas of humanization and humanitarization of education, understanding of the crucial role of culture towards nature, ecological imperative of ecological culture in solving global environmental problems. Taking into consideration the above mentioned, the effectiveness of pupils' ecological culture education technology had been developed and proved.
\end{abstract}

Keywords: ecology, ecological education, methodological approaches, axiology, axiological approach, cultural approach, culture, ecological culture, ecological culture education. 


\section{INTRODUCTION}

The use of axiological and cultural approaches as a methodological basis for the education of ecological culture of pupils should be considered as a whole because the influence of social information, educational efforts is carried out simultaneously on two levels - rational and emotional. However, each of these approaches has its own specifics. If a cultural approach is connected with knowing the essence of the person himself, interactions that occur in it, and influence on the sphere of rational thinking which is the basis of ecological culture, principles, positions, then education of ecological culture of pupils which is carried out on the basis of the use of axiological approach, is aimed to mainly to the emotional-and-sensual world of a personality and helps to form ecological culture through humanistic sensation of the world. Combination of these two approaches of influence to a personality secures formation of ecological beliefs, ethical norms of behaviour in nature, striving for self-improvement, which are realized in the process of ecological culture education.

In line with the axiological approach the phenomenon of ecological culture has been considered by the following scientists: Anisimov (2005), Bondar (2015), Krysachenko (1996), Kurnjak (2006), Labezna (2002), Pustovit (2014) and other researchers. Zahlebnyj \& Suravegina, (1984), Zverev \& Zakhlebnyi, (1985), Suravegina (1988) and others have developed the principles of environmental education at high school. Derjabo \& Yasvin, (1996) and Yasvin (2000) study psychological aspects of ecological culture. Psychological and educational research of Bech (1996), Bozhovich (1995), Vygotskij (1991), Davydov (1986) showed that only a person who is aware of itself as part of the universe, is psychologically ready to environmentally appropriate human activity.

Current studies prove that ecological education is uninterrupted from elementary level (Prabawani et.al., 2017) to higher educational institution (Nunez \& Clores, 2017) and concerns the use of different methods of teaching the pupils of secondary schools to preserve surrounding nature (Munawaroh, 2017; Harto \& Hartmann, 2017; San Jose, 2017; Torkara, 2016).

Scientists emphasize that the focus on the axiological fundamentals increasingly affects the content of environmental education. Thus, A. Liberov (2007) considers the essence of environmental education and said: "Ecology is the science of a new type, postnonclassical science whose fundamental difference from previous eras science is the inclusion of the problem of values in scientific knowledge" (Liberov, 2007; p. 24).

Axiology allows to consider the problem of the relationship between man and nature from the perspective of ecological values, learn the range of ecological values that occur in human activities, carry out educational influence on the ecological culture formation. Ecological values are a kind of values that belong to the interaction between man and nature.

Within axiological approach the varieties of values are correlated with various aspects of human nature (the spiritual, moral, psychological, and biological). The most important integrated feature of a person is a value orientation.

Based on the variety of interactions between man and nature the following types of ecological values had been defined: consumption, storage, and restoration. According to these types of values there are three types of ecological value orientations: utilitarian, preserving, and productive restoration.

Providing the main task of civilization - the restoration of self-regulatory capacity of nature by the concerted efforts of man and nature under coevolution laws - leads to understanding of the need for coordinated development of man and nature. This is possible if the leading ecological value will be the harmony of man and nature. Everything that promotes harmonization of man and nature development is ecologically valuable. 
The meaning of each type of values and human activity changes depending on whether to consider them in isolation from leading ecological orientation, content or moral subordination.

The academician M. Moiseyev (1994) considers the research system as a reason for coevolution. This system allows setting dependence of the biosphere characteristics from human activity. "Just having enough understanding of the nature of this relationship, we can formulate the restrictions on human activity that are necessary to ensure a person's future". E. Kogay (2002) refers the following imperatives to the principles of coevolutionary paradigm: "rejection from rational-technocratic paradigm based on mechanistic concepts of strict determination of the world; synergistic approach, nonlinear thinking, productive integration of science and the humanities; refusal in representations of relationships in the system "man - nature" of the extreme positions of anthropocentrism and biocentrism, aiming at overcoming the polarities; implementation of epistemological and axiological methodologies convergence in establishing a single coherent worldview; the formation of collective, planetary thinking instead of a limited focus on the urgent needs; significant increase in socio-natural components in social and natural being, enhancing the role of the humanitarian component of the cognitive process, implementation of scientific knowledge into general content of a single culture".

According to M. Moiseyev (1994), axiological basis of ecological culture contains ecological imperative as its essential characteristic and acts as a system of limitation, which break may have irreversible consequences for the further existence as a human being and the world. The ecological imperative includes the following postulates: "the focus should be on someone who has the right to a healthy and productive life in harmony with nature; preservation of equal opportunity and the environment for present and future generations; environmental protection must be an integral part of the socio-economic progress and can not be considered in isolation from it; unlike the practice of environmental protection, the prevailing emphasis should move to implement the measures on ecologization of economic activity, primarily to remove the causes of negative anthropogenic influences rather than their consequences; socio-economic development should be directed to improving the life quality within acceptable limits of economic capacity of ecosystems; ecologization of consciousness and outlook of people, the system of education and training".

In this sense, ecological culture, in turn, is the ability of realization and positive transformation of relations of the individual with the world. It serves as an active transformative beginning based on ecological imperative - which means internal axiological attitude: "ecological way of thinking that is formed in the process of learning different set of consumer impact on the environment in order to achieve proper economic impact and quality of life without degradation of the environment" (Nesgovorova \& Savinykh, 2009; p. 192-199).

The analysis of the publications of scientists that reveal the essence of the axiological approach in the interaction of man and nature showed that researchers define it as a kind of philosophical and pedagogical strategy (co-evolution, ecological imperative), which is based on the idea of the priority of universal values and the value of each individual. This approach is traditionally considered the methodological basis of humanistic-oriented pedagogical education, since it involves the formation of humanistic values of personality in the process of its implementation.

However, scientists have closely studied personal attitude of pupils to restorative type of interaction between a man and nature, their ability to project their future activity at the level of values of renewal, to contribute to the formation of world-view beliefs which determine behaviour and character of a person's activity. In addition, content of this activity, methods of 
its conducting, reflexive self-appraisal, managerial actions in relations with nature were not revealed.

Thus, the choice of axiological approach as a methodological basis for ecological culture education of pupils allows us to consider it as a phenomenon that has a valuable status, which acts in two main aspects: 1) in social because value is a priority in social consciousness first and only then changes to sociocultural priorities; 2) in personal because ecological culture is primarily internal, own property of a personality.

Cultural approach to ecological culture education allows determining the ratio of the general ecological culture and spiritual culture, considering the relationship between three social and natural subjects: people, culture, and nature Modern scientists (Pankina et.al., 2016; Ridei et.al., 2013; Dartey-Baah, 2013; Verdu-Jover et.al., 2017) examined ecological culture and its varieties. Researchers take a significant role to ecological culture as an indicator of steady development of relations between society and nature.

Methodology of cultural approach is natural for education of ecological culture, and leads to the recognition of its spiritual meaning. According to O. Anisimova (2005), "culture of a new quality, implements essential powers of a human, his spiritual and moral potential, harmonizes the relation of mind, consciousness and human existence" (Anisimov, 2005; p. 38).

Ecological culture is a kind of common culture that allows, in terms of the harmonious development of society and the biosphere, to carry out interrelated activities to the use, conservation and restoration of vital forces of the nature; during its historical development, it increases a syncretic potential that converts general culture into the ecological one.

Cultural approach to ecological culture education of pupils means that the subject of activity has to orient to self-affirmation of true human principles and qualities. In this sense a famous scientist A. Ivashchenko et al. (2008) considered the vital values and attitudes as the structure components of ecological culture. These vital values and attitudes are based on the intrinsic value of the surrounding nature and the planet in general, and human conviction that it also includes ways of knowing the world of nature, environmental norms of behavior and personal (subjective) attitude to the world of nature, motivation and need sector (Ivashchenko et al., 2008; p. 219).

For educational research cultural approach opens up a wide range of ecological and educational facilities, techniques and various teaching forms of environmental education. Activity aspect of the ecological culture is subordinated to spiritual aspect.

So, ecological culture unites man and nature, creates the basis for the development of social and natural systems based on values, the opposite to the values of modern consumer society. Culture, which is formed on the values of harmony between man and nature in order to preserve the integrity of the human race and nature regulatory capacity, is the only way to guarantee unity of man and nature.

Considerations of mentioned above show that the tasks of cultural approach to ecological culture education of pupils are not only its preservation, transmission, reproduction and development, but also creation of conditions for self-development of a personality by means of culture; mastering of cultural values necessary to achieve activity; development of abilities and skills to preserve environment.

Being in unity with the axiological approach, the cultural approach to ecological culture education leads to the conclusion that ecological culture can only develop in a holistic educational process that reflects its axiological, informational, emotional, and behavioral content. 
Analysis of scientific literature shows the need for a thorough study of methodological bases, in particular, axiological and cultural approaches to ecological culture education of pupils.

Purpose of the article is to reveal the main methodological approaches (axiological and cultural) and their application for the development of educational technology of ecological culture of pupils.

Tasks: 1) to reveal the essence of axiological and cultural approaches to ecological culture education of pupils, 2) to substantiate the components of ecological culture of pupils, 3) to develop the technology of ecological culture education of pupils and to reveal its stages, 4) to carry out the diagnostics of education of pupils' ecological culture in the process of implementation of the developed technology.

\section{METHODS AND MATERIALS}

The following methods were used in the process of the research as theoretical: analysis and generalization of philosophical, psychological-and-pedagogical, scientific-and-methodical and educational literature on the research problem which made it possible to determine methodological bases of the studied problem, empirical: observation, conversation which gave the opportunity to gather primary analytical material concerning education of ecological culture of pupils; pedagogical experiment for checking the effectiveness of developed technology of ecological culture education of pupils.

Such methods as: test "Self-appraisal of ecological culture" and a situational questionnaire "ECUL" ("ecological culture") were used for conducting diagnostics of ecological culture education of pupils.

\section{RESULTS AND DISCUSSIONS}

The current stage of development of relations between human society and nature is characterized as a transitional and crisis. In the Encyclopedia crisis (from the Greek. krísis) means a decision, a turning point, the result a turning point, a difficult transition state, acute, dangerous unstable position (1978). On the one hand, this is a crisis of natural ecosystems; on the other hand it is a deep ontological crisis of human existence. A person shows great persistence towards environmental protection, elimination of consequences of environmental disasters, less persistence in the prevention of technogenic effects of adverse ecological events, almost complete passivity in decision making in the formation of the corresponding type of consciousness, attitudes, behaviors and activities that can not go beyond the harmonious coexistence and adequate life that do not influence the nature destruction, and, in a result, do not influence the human (Grishaeva, 2014; pp. 103-105).

At the present stage of the development of the ecological crisis, attention was intensified not only to the education of the ecological culture of the students, but also to the improvement of this process, which we propose to implement through: the disclosure of environmental problems, attempts and ways of their solution to young generations, the application of various methodological approaches, in particular axiological and culturological, The formation of the ecological culture of students, the introduction of technological aspects of ensuring the effectiveness of this process.

The ecological crisis increases rapidly. A famous scientist M. Moiseyev (1997), grounding the theory of noospheregenesis, noted that in fact, it is based on new principles of morality, a new system of morality that should be universal for the entire planet, for all the differences 
of peoples' civilizations that inhabit it. In terms of ecological crisis the inability of the modern global community to cope with it is clearly seen.

The alienation of man from nature, its quasiproductive livelihoods on the one hand and the inability to exist without natural resources and environment (clean air, drinking water, fertile soil, natural characteristics of the environment, etc.) on the other hand, is, obviously, a serious problem of adequacy of human existence, its coexistence in the global ecosystem. However, all the attempts to solve ecological problems (both at global and local levels) come to the elimination of irrational nature use consequences. The essence of ecological problems is still seen in environmental pollution by economic activity wastes, and the ecology task is to prevent, clean, restore the things which have been broken. This is "ecology of effects" that does not explain the reasons for this situation and therefore not able to fix it. It does not reach the holistic, philosophical views on human livelihoods and does not consider that the state of nature and culture is interdependent (Kutyriev, 2009; p. 49).

Practical experience shows that poor knowledge, unformed views on the problem of interaction between a man and nature lead to indifferent, selfish attitude of pupils to the use of natural resources, preservation of the surrounding nature, that is inadmissible in the process of educating the sense of own responsibility for environment preservation.

Generally, we note the contradiction between the need to nursing a high level of ecological culture and the lack of scientific and pedagogical grounding of the essence of this process, that needs to develop appropriate technology and stages of its fulfillment.

A great importance for overcoming mentioned contradictions and development of technology for educating ecological culture of pupils has the revealing of value and cultural aspects in solving these problems that connects with the necessity to apply axiological and cultural approaches.

Using of axiological approach gave the opportunity to reveal the components of ecological culture of pupils which include: ecological and values orientations, ecological and meaningful knowledge, adequate ecological and value relationships, ecological and justified activities.

Ecological and value orientations are the individual's expressed vectors of advantages of ecological values of a certain type of human interaction with nature and the willingness of the individual to practice according to the chosen types of interaction with nature.

Ecological and values relations cover the whole range of intellectual, moral, and aesthetic feelings that arise in the child during its familiarity with environmental problems or in direct contact with nature and the adoption of certain types of interaction between man and nature.

Ecological and meaningful knowledge is knowledge important to establish efficient interaction between man and nature. They include: natural sciences; knowledge of the unity of animate and inanimate nature; knowledge of the social and natural system; knowledge about man-made factors, environmental problems and their solutions; knowledge of natural elements monitoring; experience in environmental management, conservation and restoration of nature; regulatory knowledge.

Ecological justified practical activity is expressed in various forms: personal participation in the conservation and restoration of lost items; environmental monitoring; active promotion of environmental ideas and principles of ecological imperative; projecting and practical activity on interaction with nature.

To solve these problems, there was a need to find effective ways to ensure the process of raising the ecological culture of pupils, raising their level of education, forming the appropriate type of consciousness, relations, behavior and activities, in particular, developing and implementing a phased technology for raising the ecological culture of pupils. 
Lisdiyono (2017), Dobrogoszcz (2017), He \& Wiggins (2017) pay attention to the need of solving these problems by different ways.

The ecological crisis is a crisis of technocratic society values based on consumption of natural resources, to create wealth and conditions for comfortable life. Ecological problems solution is impossible without changing value orientations of the general population, secondary school pupils' ecological education.

Attention to ecological culture education of pupils has increased at the present stage of the development of ecological crisis. But experience of its purposeful and systematic implementation in educational institutions has not yet been sufficiently spread. There is a significant gap between program requirements and factual knowledge, relevant views and beliefs of pupils, between the need to educate ecological culture of pupils and educational facilities of educational institutions, there is no ensuring of unity of school and extracurricular activities of pupils, theoretical knowledge and practical actions. Inconsiderable attention is paid to nature conservation work as one of the conditions of environment preservation. Pupils' knowledge about the need of ecologizing of all spheres of life does not turn into persistent beliefs.

Despite significant progress in the development of environmental education, the ecological culture level of the majority of pupils of different types of educational institutions remains low. The utilitarian approach to nature prevails, the attitude to environmental issues is not included in personal values, and it is not a part of the moral beliefs. Pragmatic orientation of environmental skills predominates. Much attention is paid to activity part of ecological education, and at the same time weakening of thematic and value basis, which can stop the consumer and destructive orientation of practice interaction with nature.

The leading component in the structure of ecological culture are ecological and value orientations. We developed the technology of ecological culture education, where you can conduct the following:

- movement from one type of ecological values (ecological and value orientation) to another by the chain: the value of consumption - saving value - value of restoration;

- changing the way of teaching and learning activities that accompany the transition of knowledge from one type of value orientations to another. In general terms, the ways of pupils' activity to form different level values are based on the following principle: from reproductive through partially search to creatively projecting activities with the increased subjective position of pupils;

- change the reflection of pupils on the basis of ecological culture levels: pupils evaluate themselves and their actions from the standpoint of various types of ecological values;

- change the pupils' cognitive activity management according to the levels of ecological culture; it is connected with the change of subject position of the individual in terms of relationship between man and nature.

There are three levels of ecological culture manifestation: low, medium and high.

The low level of ecological culture education based on the utilitarian type of values. It is characterized by the assimilation of terms and concepts that reveal the main features and properties of the ecosystems, some knowledge of environmental issues. We can define inability to disclose the nature and character of causality in the relationship between man and nature, to transfer knowledge to solve specific environmental problems has been determined. We can follow the unstable and situational interest in nature. Utilitarian nature of the interaction of natural objects is approved. Projected behavior is not ecologically right, and its implementation is able to damage the nature and leads to environmental degradation.

The medium level of ecological culture education reflects the preserving type of ecological and values orientation. It is characterized by incomplete knowledge on the environment; it is 
marked by understanding of the complexity of environmental problems, awareness of the importance of nature conservation. Its own role in solving environmental problems is quite recognized. Moral and aesthetic feelings associated with the preservation of nature are clearly expressed. The projective activity has ecologically grounded character and is aimed at nature preservation.

A high level of ecological culture is associated with productive restoration type of ecological and values orientation. There is a wide range of ecological and valuable knowledge, its integration and use in the analysis and evaluation of events in terms of their environmental relevance, justification to harmonize the relationship between man and nature and possible ways of their implementation; awareness of need and knowledge of the ways to solve environmental problems through restoration and enhancement of natural resources. The projected activity has restoration character in the interaction with nature. Personal activity in work, aimed at improving the environment is revealed.

All types of values are evaluated in a single logic - the logic of coevolution and ecological imperative.

We developed the technology of ecological culture education which is carried out in three stages, each of which is seen at the following levels: content, methodological, reflexive, and managerial.

Stage 1: understanding the value of consumption and its consequences, the task of which is to develop the ability to provide the consumption value in the studied material; give the characteristic to the consumption values in terms of human needs; evaluate the utilitarian type of interaction between man and nature, to express their attitude to it; ensure pupils' understanding to review the relationship between man and nature on the basis of new value. At the content level the attention is focused on information on the use and pollution of environmental components, methodological level provides pupils' activities must have reproductive character; efforts are focused on awareness of the problem of environmental use and pollution; nature of tasks are gradually complicated and the transition is made to partially search level, reflexive level provides a personal assessment of their own attitudes to the values of consumption, managerial level the conditions that allow pupils to sharpen negative attitude to the utilitarian type of interaction with nature have been created.

Stage 2: understanding the value of conservation and their meaning, the tasks of which are: the formation of the ability to allocate the conservation value in the studied material and to distinguish them from the values of consumption; define the features of preservation type of interaction between man and nature; learn to analyze the meaning and environmental activities consequences, making a personal attitude; explain pupils the need to build a relationship with nature based on restoration. At the content level, ecological nature information on the principles, methods, and forms of environmental protection has been chosen, methodological - the activities of teachers and students are formed, the problem of environmental cooperation is solved; pupils' emotional experience in relationships in conjunction with real environment based on the idea of savings is organized, reflexive level provides pupils are aware of the need to solve the problems of environmental nature, managerial - the conditions that allow transferring the chosen type of interaction with the natural objects in favor of environmental activities are created.

Stage 3: formation of restoration values of the environment, the task of which is to develop the ability to provide value restoration in the studied material; to form a personal relationship to restorative type of interaction between man and nature; learn to project their future activities at the level of values restoration; promote philosophical and ideological generalizations which, becoming beliefs and life principles determine the behavior and character of the individual. At the content level, priority is given to the information about 
restoring natural sites, methodological - pupils' understanding of the restoration values meaning in project activity has been organized, reflective - self-assessment is carried out during the design activity, the pupils personally come to the conclusion about the efficiency of the chosen system of values in the project activity, comparing it with the activities of peers, managerial - the conditions under which a person can show his most positive intentions in the relationship with nature have been created.

Technological procedure involves forward movement of the ecological values to a higher level that preserves the stages' continuity.

To implement the technology of educating of pupils' ecological culture and to check its effectiveness, we conducted a diagnosis of ecological culture education of pupils with the help of specially developed methods: 1) the test "Self-assessment of the Ecological Culture", which made it possible to obtain information about the general ecological culture of an individual, about value orientations of ecological and meaningful knowledge, attitudes and desired activity of the individual. The natural situations that have been asked, are variable; any teacher can change the content of the test in the educational practices; 2) situational questionnaire "ECCUL" ("ecological culture") is developed to define the level of ecological culture in specific educational situations and certain elements of the environment. The questionnaire helps to monitor the dynamics of ecological culture as a whole and its individual components, which makes it possible to make timely adjustments to the process of ecological culture education.

The evaluation of the results of ecological culture education based on gradual revealing: value orientations of each component of ecological culture, type of value orientation of a personality, level of ecological culture by the type of value orientations of a personality.

Types of interaction between man and nature, types of ecological and value orientations, types of ecological and meaningful knowledge, ecological and value relationships, ecological and justified activity are underlying the rating scales from minimum ecological culture manifestation to maximum.

On the basis of the proposed methodologies usage the experimental research on pupils' ecological culture education in the learning process has been conducted. 104 high school pupils were involved in the study, which was conducted under general subjects (biology, ecology, and geography) and elective courses.

Educational materials of ecological and environmental protection content (technology, description of lessons, methodological guidelines) have been implemented during the experiment.

According to the results of the conducted experiment, the experimental groups, in comparison with the controlled ones, showed a significant increase in the number of pupils who have a high level of ecological culture education; we can also follow the transition of pupils from the preserving to restoring level of the ecological culture; significantly fewer pupils who showed a low level of education ecological culture.

\section{CONCLUSIONS}

Thus, we have revealed the essence of axiological and cultural approaches to ecological culture education of pupils. Axiological approach as a methodological basis for educating ecological culture considers ecological culture as one of the leading value orientations of modern society which allows personality to make his life meaningful and determine: value orientations, ecological knowledge, adequate ecological-and-value relationships, ecologically justified activities. Educating of ecological culture of pupils, from a cultural approach point, serves as a process of creating the conditions for a personality 
self-development by means of culture; his mastering of cultural values necessary to achieve the activity; development of abilities and skills to preserve surrounding environment.

Components of ecological culture of pupils were substantiated in the course of research including: ecological-and-value orientations, ecologically significant knowledge, adequate ecological-and-value relations, ecologically-justified activity.

Stage-by-stage technology of educating pupils' ecological culture was developed; it was carried out by three stages, each of them was considered at the following levels: content, methodological, reflexive, and managerial.

Diagnostics of educating pupils' ecological culture in the process of fulfilment of the developed technology, which showed that there was a changing of pupils from a low level to medium and partly high level of ecological culture education; there was a decrease in the number of pupils who showed a low level of ecological culture education.

Conduced research will serve as an impetus for further exploration in application of axiological and cultural approaches for the development of scientific-and-methodological support for the process of ecological culture education of pupils.

In the future, it is planned to continue research concerning substantiation of other methodological approaches to ecological culture education of pupils, in particular system, integrated, humanistic and personality-and-active and creation conditions for implementation of this technology in different types of educational institutions (comprehensive schools, institutions of primary and secondary vocational education).

\section{REFERENCE}

Anisimov, O. (2005). Jekologicheskaja kul'tura: voshozhdenie $k$ duhu. Poiski duhovno-nravstvennyh osnovanij korrekcii obrazovanija i kul'tury. Moscow.

Bech, I. (1996). Psychology of values and educational process. Big Soviet Encyclopedia. (2008). Moscow. Retrieved 6 March 2008, from: http://www.alleng.ru/d/inform/inform 025.htm.

Bondar, O. (ed.). (2015). Environmental education for sustainable development in questions and answers: scientific and methodical manual for teachers. Kherson: Grin D.S., 228 p.

Bozhovich, L. (1995). Problems of personality formation: selected psychological works. Voronezh: Modec, $352 \mathrm{p}$.

Dartey-Baah, K., (2013). The Cultural Approach to the Management of the International Human Resource: An Analysis of Hofstede's Cultural Dimensions. International Journal of Business Administration, 4(2). 39-45.

Davydov, V. (1986). Problems of developmental learning. Experience of theoretical and experimental psychological research. Moscow: Pedagogy, $240 \mathrm{p}$.

Derjabo, S. \& Yasvin, V. (1996). Ecological pedagogy and psychology. Rostov-na-Donu: Feniks. 480 p.

Dobrogoszcz, T. (2017). The planet heals itself: The overkill of Homo sapiens in the contemporary literature European Management Journal. Retrieved 15 April 2017, from: https://www.researchgate.net/publication/318964807_The_planet_heals_itself_The_overkil 1_of_Homo_sapiens_in_the_contemporary_literature.

Grishaeva, Ju. (2014). The concept of formation of ecological and professional competence of students of the humanitarian university. Moscow: Sholokhow Moscow State University for the Humanities. 38 p. 
Harto, W. \& Hartmann, M. (2017). Evaluating the Implementation of Green School (Adiwiyata) Program: Evidence from Indonesia. International Journal of Environmental \& Science Education. (August 11). 1483-1501.

He, Y. \& Wiggins A., (2017). Implementing an Environmental Citizen Science Project: Strategies \& Science Education. (August 11). 1459-1481.

Ivashchenko, A., Panov, V. \& Gagarin, A. (2008). Ecologically-oriented worldview of skiing. Moscow: RUDN. 225 p.

Kogay, E. (2002). Ecological paradigm of culture and education. Social and humanitarian knowledge, 4, 118-119.

Krysachenko, V. (1996). Ecological Culture: Theory and Practice. Kyiv: Testament. 352 p.

Kurnjak, L. (2006). Formation of ecological culture as a priority of modern educational policy. New paradigm. Philosophy. Politology. Sociology, 55, 65-71.

Kutyriev, V. (2009). Being or nothing. Saint-Petersburg: Aletejja. 496 p.

Labezna, O. (2002). Formation of the ecological culture of the individual: to the problem statement. Problems of higher pedagogical education in the light of decisions of the II All-Ukrainian Congress of Education Workers, 2, 209-211.

Liberov, A. (2007). Ecodidactics: ecosystem methods of training design. Moscow: Institut jekonomicheskih strategij. $108 \mathrm{p}$.

Lisdiyono, E. (2017). Environmental Legislation: a Study of the Shift of Spatial Policy in Local Regulation. International Journal of Environmental \& Science Education, 12, 597-605.

Moiseyev, N. (1994). Morality and the phenomenon of evolution. Ecological imperative and ethics of the XXI century. Social sciences and modernity, 6, 131-139.

Moiseyev, N. (1997). Coevoluation of nature and society of the path of nosopherogenesis. Retrieved 20 January 2017, from: http://www.ecolife.ru/jornal/echo/1997-2-1.shtml.

Munawaroh, (2017). The Influence of Teaching Methods and Learning Environment to the Student's Learning Achievement of Craft and Entrepreneurship Subjects at Vocational High School. International journal of environmental \& Science education, 12, 665-678.

Nesgovorova, N. \& Savinykh, V. (2009). An Integrative Approach to Environmental Education. Philosophy of education, 1, 192-199.

Nunez, M. \& Clores, M. (2017). Environmental Literacy of K-10 Student Completers. International journal of environmental \& Science education, 12, 1195-1215.

Pankina, M., Khrustalyova, C. \& Egarmin, A. (2016). Role of Design in the Consumer Culture Development: Ecological Context. International journal of environmental \& Science education, 11, 8771-8780.

Prabawani, B., Musfirowati, H. \& Pradhanawati, A. (2017). Primary Schools Eco-Friendly. Education in the Frame of Education for Sustainable Development, 12, 607-616.

Pustovit, N., Kolon'kova, O. \& Prucakova, O. (2014). Formation of environmentally expedient behavior of schoolchildren. Kirovograd: Imeks-LTD. $140 \mathrm{p}$.

Ridei, N., Rybalko, Y. \& Kycherenko Y., (2013). The role of ecological culture as an indicator of sustainable development of relations between society and nature. European Scientific Journal, 2, 14-23.

San Jose, A., (2017). Nelson Increasing Children's Positive Connection To, Orientation Toward, and Knowledge of Nature through Nature Camp Experiences. International Journal 
of Environmental \& Science Education. (June 17). 933-944.

Suravegina, I. (1988). About methods of formation of the responsible relation of schoolboys to the nature. Biology at school. 3. 10-14.

Torkar, G. (2016). Secondary School Students' Environmental Concerns and Attitudes toward Forest Ecosystem Services: Implications for Biodiversity Education. International Journal of Environmental \& Science Educatio, 11. 11019-11031.

Verdu-Jover, A., Alos-Simo, L. \& Gomez-Gras, J.-M. (2017). Adaptive culture and product/service innovation outcomes European Management Journal. Retrieved 2 Juny 2017, from: https://www.researchgate.net/publication/318472502_Adaptive_culture_and_product service_innovation_outcomes.

Vygotskij, L. (1991). Pedagogical psychology. Moscow: Pedagogika. 479 p.

Yasvin, V. (2000). Psychology of attitude toward nature. Moscow: Smysl. 456 p. Kogaj, E. (2002). Ecological paradigm of culture and education. Social and humanitarian knowledge, 4, 118-119.

Zahlebnyj, A. \& Suravegina, I. (1984). Ecological education in extracurricular work. Moscow: Prosveshhenie. 157 p.

Zverev, I. \& Zakhlebnyi, A. (1985). Environmental knowledge in class and after school. National education, 2, 81-84. 